\title{
Mechanical Stress Dependence of Power Device Electrical Characteristics
}

\author{
Masanori Usui Non-member (TOYOTA CENTRAL R\&D LABS., INC.) \\ Hiroaki Tanaka Non-member (TOYOTA MOTOR CORPORATION) \\ Hotta Koji Non-member (TOYOTA MOTOR CORPORATION) \\ Satoshi Kuwano Member (TOYOTA MOTOR CORPORATION) \\ Masayasu Ishiko Member (TOYOTA CENTRAL R\&D LABS., INC.)
}

Keywords: mechanical stress, power device, deformation potential model, piezoresistive effect model

Inverter modules which adopted power devices have been used for the power control of hybrid electric vehicles. Reduction in the thermal resistance is important for the inverter modules because one of the requirements of the inverter modules is the realization of high power density, i.e. downsizing and high output power. Recently, new power module structures have been proposed. However, thermo-mechanical stress is expected to be larger in those structures. Although the interconnection reliability of power modules has been studied, few reports have focused on the influence of mechanical stress. The purpose of this paper is to analyze the effects of mechanical stress on vertical power devices.

In an actual power module, both the device current and the cooling characteristics are distributed over a range of values, so thermal stress is not uniform. It is therefore not easy to predict the effects of thermal stress on electrical characteristics in practical situation. The four-point-bending technique, which had been used for the stress dependence measurement of lateral MOSFETs, was modified for vertical power devices. To produce a uniform stress along the vertical direction, the test device was fixed to a baseplate, as shown in Fig. 1. Planar IGBT (Insulated Gate Bipolar Transistor) and trench IGBT were chosen as test devices. Those devices were punch-through type IGBTs on a (001) wafer, and mechanical stress was applied in the [110] or [110] directions.

Fig. 2 and 3 show the stress dependence of the on-state voltage on trench IGBT and planer IGBT. In case of a planer IGBT, stress dependence differs according to whether the stress is applied in the [110] direction (parallel to the channel formation direction) or the [1110] direction (perpendicular to the channel formation direction). In case of a trench IGBT, the changes of on-state voltage in the [110] and $[\overline{1} 10]$ direction are similar. This is due to the fact that in a planer IGBT, the channel formation direction is in the same plane as the direction in which stress is applied, so the channel mobility changes according to the direction in which stress applied.

This consideration gives us the important information for designing a power module with higher output density.

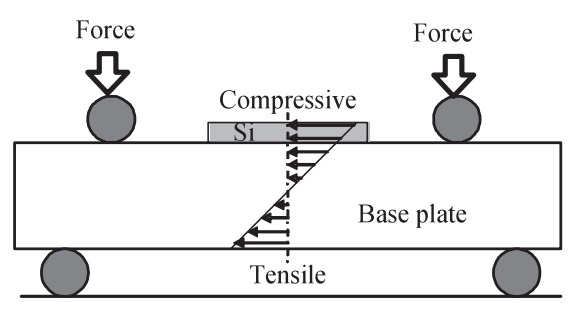

Fig. 1. Novel four point bending technique

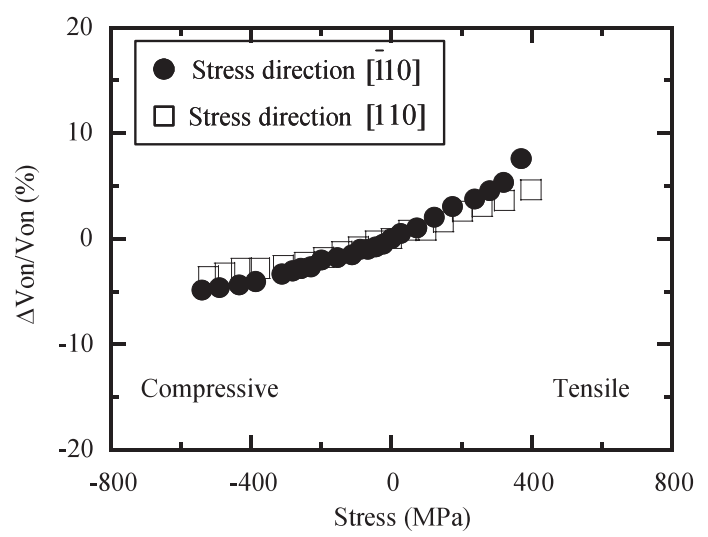

Fig. 2. Stress direction dependence of on-state voltage at $\mathrm{Jc}=230 \mathrm{~A} / \mathrm{cm}^{2}$ on trench IGBT (Measurement)

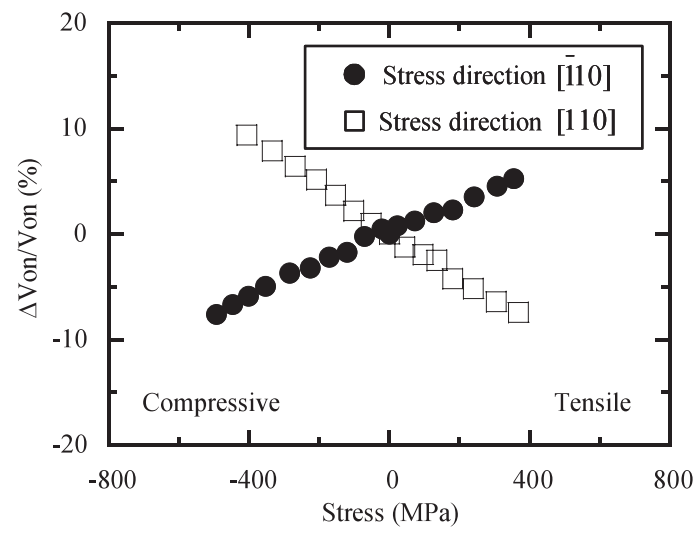

Fig. 3. Stress direction dependence of on-state voltage at $\mathrm{Jc}=230 \mathrm{~A} / \mathrm{cm}^{2}$ on planer IGBT (Measurement) 


\title{
パワーデバイス電気特性の機械的応力依存性
}

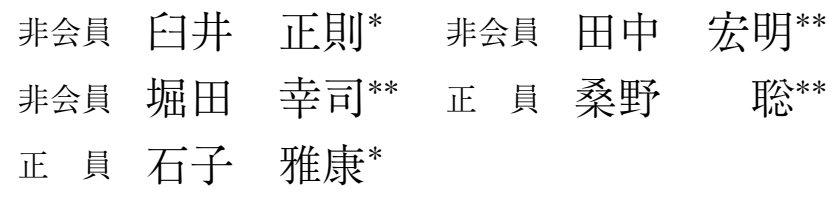

\section{Mechanical Stress Dependence of Power Device Electrical Characteristics \\ Masanori Usui*, Non-member, Hiroaki Tanaka**, Non-member, Hotta Koji**, Non-member, Satoshi Kuwano**, Member, Masayasu Ishiko*, Member}

\begin{abstract}
This paper describes how mechanical stress affects the electrical characteristics of power devices, depending on the surface structure of the device and stress direction. We applied ideal external uni-axial stress to the various power devices, and studied the mechanism by comparing results from experiments and simulations. We found that the stress dependence of the on-state voltage mainly arose from the MOSFET portion of the IGBT. This consideration gives us the important information for designing a power module with higher output density.
\end{abstract}

キーワード : 機械的応力, パワーデバイス, ポテンシャル変形モデル, ピエゾ抵抗効果モデル

Keywords: mechanical stress, power device, deformation potential model, piezoresistive effect model

\section{1. はじめに}

ハイブリッド自動車が持つ高い燃料効率やクリーンな排 気ガスといった優れた特性は, 地球環境に対して大きな役 割が期待されている(1)(2)。ハイブリッド自動車においてパ ワーモジュールは，ジェネレータ，モータ，バッテリ間の 電気エネルギの流れをコントロールする重要な構成要素で ある。このパワーモジュールへの要求は, 小型・高出力化, 言い換えれば，高電力密度化である。高電力密度化には， デバイスの低損失化だけでなく，冷却性能の向上が必要と なる。冷却性能向上が可能なモジュール構造として, 近年, Fig. 1(a) に示すような構造 (3)(4) が提案されている。しかし ながら, Fig. 1(a) に示すようなモジュール構造では, デバ イスと実装基板との間で熱膨張係数が大きく異なるため, Fig. 1(b) に示すような従来のモジュール構造に比べて, デ バイス水平面に平行な方向の熱応力の増大が懸念される（た とえば，低熱抵抗材料である銅にシリコンデバイスを実装 した場合，温度差を $200^{\circ} \mathrm{C}$ とすると，デバイスの熱応力 は最大 $500 \mathrm{Mpa}$ 程度と見積もることができる)。このよう

\footnotetext{
*（株）豊田中央研究所

₹ 480-1192 愛知県愛知郡長久手町大字長久手字横道 48-1

TOYOTA CENTRAL R\&D LABS., INC.

Nagakute, Aichi-gun, Aichi 480-1192

**トヨ夕自動車（株）

干 470-0309 豊田市西広瀬町桐ケ洞 543

TOYOTA MOTOR CORPORATION

543, Kirigahora, Nishihirose, Toyota 470-0309
}

に, 熱応力が増大すると, はんだ接合やワイヤボンドといっ た金属接合部の信頼性だけでなく，パワーデバイス特性へ の影響も懸念される。以前より，パワーモジュール接合部 の信頼性についての研究報告は多い(5)(6) が, パワーデバイ スの電気特性への影響についての報告は少なかった。そこ で, 我々は前報告にて機械的応力がトレンチタイプの IGBT (Insulated Gate Bipolar Transistor) の電気特性に与える影 響を，はじめて計測・評価した (7)(8)。これに対して，本報告 では，前報告で未検討であったデバイス電気特性に対する 応力方位依存性, 及び, デバイス構造依存性を明らかにす ることを目的とする。

本報告では，まず，機械的応力によるシリコン結晶の特性

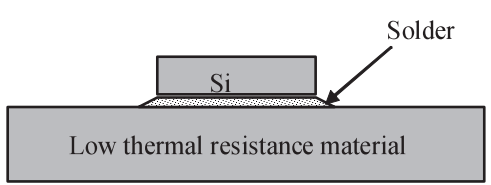

(a) Novel structure

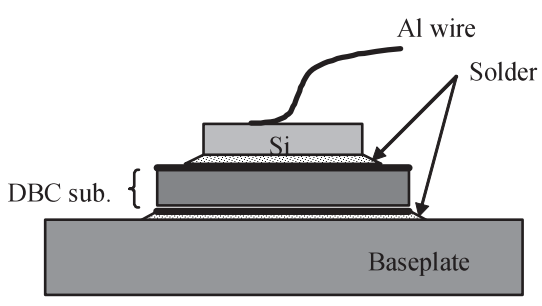

(b) Conventional module structure

Fig. 1. Schematic cross-section of power module 
変動モデルを示す。次に, 縦型パワーデバイス評価用に開 発した，応力依存性の計測方法について示す。さらに，こ の手法を用いて実施した応力方位依存性，デバイス構造依 存性についての計測結果について示す。また，スイッチン グ特性への影響についても示す。

\section{2. シリコン結晶への機械的応力の影響}

シリコンに応力が印加された場合の特性変動に関して, 主なものとして次に 2 つモデル提案されている。バンド 端のポテンシャルの変化に着目したポテンシャル変形モデ ル (9) と，キャリア移動度の変化に着目したピエゾ抵抗効果 モデル(10)である。

〈2·1〉 ポテンシャル変形モデル 一般化されたフッ クの法則により，シリコンの歪み $\varepsilon_{i}$ は次式のように応力 $T_{i}$ で表すことができる。

$$
\varepsilon_{i}=\sum_{j=1}^{6} S_{i j} T_{j}
$$

ここで, $S_{i j}$ は弾性コンプライアンス, $\varepsilon_{1} \sim \varepsilon_{3}$ は 垂直歪み成分, $\varepsilon_{4} \sim \varepsilon_{6}$ は剪断歪み成分, $T_{1} \sim T_{3}$ は 垂直応力成分, $T_{4} \sim T_{6}$ は剪断応力成分である。

シリコンのエネルギーレベルに対する弾性歪みの影響は 次式で与えられる(9)。

$$
\begin{aligned}
\Delta E_{k}^{B}= & \xi_{k_{1}}^{B}\left(\varepsilon_{1}+\varepsilon_{2}+\varepsilon_{3}\right)+\xi_{k_{2}}^{B}\left(\varepsilon_{1}-\varepsilon_{3}\right)+\xi_{k_{3}}^{B}\left(\varepsilon_{2}-\varepsilon_{3}\right) \\
& +\xi_{k_{4}}^{B} \varepsilon_{4}+\xi_{k_{5}}^{B} \varepsilon_{5}+\xi_{k_{6}}^{B} \varepsilon_{6} \ldots \ldots \ldots \ldots \ldots \ldots \ldots \ldots
\end{aligned}
$$

ここで, $\xi_{k j}^{B}$ はポテンシャル変形定数である。なお, (2) 式の添字 $B$ は，C が伝導帯に，V が価電子帯 に相当する。また，添字 $k$ は等エネルギ面の数を 示し，伝導帯の場合 $(B=\mathrm{C})$ は $k=3$, 価電子帯 の場合 $(B=\mathrm{V})$ は $k=2$ となる。

マクスウェル・ボルツマン分布を仮定すると,バンドギャッ プ変化 $\Delta E g$ は次式で表すことができる。

$$
\begin{aligned}
\Delta E g= & \Delta E_{\text {average }}^{C}-\Delta E_{\text {average }}^{V} \\
= & \left\{-\log \left[\frac{1}{3}\left(\sum_{k=1}^{3} \exp \left\{-\Delta E_{k}^{C} / k T\right\}\right)\right]\right\} \\
& -\left\{\log \left[\frac{1}{2}\left(\sum_{k=1}^{2} \exp \left\{\Delta E_{k}^{V} / k T\right\}\right)\right]\right\} \cdots
\end{aligned}
$$

Table 1. Piezoresistance coefficients on (001) silicon wafer (The units are $10^{-11} \mathrm{~Pa}^{-1}$ )

\begin{tabular}{|c|c|c|r|c|}
\hline \multirow{2}{*}{$\begin{array}{c}\text { Current } \\
\text { direction }\end{array}$} & \multirow{2}{*}{$\begin{array}{l}\text { Stress } \\
\text { direction }\end{array}$} & \multicolumn{3}{|c|}{ Piezoresistance coefficients } \\
\cline { 3 - 5 } & $\Pi$ & N-type & P-type \\
\hline \multirow{2}{*}[001]{} & {$[001]$} & $\Pi_{l}=\Pi_{11}$ & -102.2 & 6.6 \\
\cline { 2 - 5 } & {$[110],[110]$} & $\Pi_{t}=\Pi_{12}$ & 53.4 & -1.1 \\
\hline
\end{tabular}

〈2・2〉 ピエゾ抵抗効果モデル＼cjkstart導通状態におけるデバ イス特性の応力依存性の予測には, 次式が使われている ${ }^{(10)}$ 。

$$
\Delta \mu_{i} / \mu_{0}=\overline{1}-\sum_{j=1}^{6} \Pi_{i j} T_{j} .
$$

ここで, $\overline{1}$ は, 単位テンソル, $\mu_{i} / \mu_{0}$ は移動度の変 動率, $\Pi_{i j}$ はピエゾ抵抗係数である。

Table 1 に，(001) シリコンウエハのピエゾ抵抗係数を示 す ${ }^{(10)}$ 。例えば，通電方位が [001] の時，[110] 方向に圧縮 応力 $100 \mathrm{MPa}$ 印加された場合，電子の移動度は 5.34\%増加 し，正孔の移動度は $0.11 \%$ 低下することになる。このよう に, 応力によるキャリア移動度の変化は, キャリアの種類, 通電方位，応力方位により異なる。

\section{3. 実験方法}

Fig. 2 に，低熱抵抗材料である銅製の基板にパワーデバイ スを加熱接合 $\left(250^{\circ} \mathrm{C}\right)$ し，室温に戻した際に発生した熱応 力分布の FEM (Finite Element Method) による計算例を示 す。この例のように，パワーデバイスに発生する機械的応 力は，デバイス中心部と周辺では等しいわけでなく応力分 布が生じている。また，デバイスの動作時は自己発熱によ り温度が上昇するが，その電気特性は温度依存性を持って いる。したがって，現実的な構造では，応力分布に加えて デバイス温度も変動要因となり，これを対象とした解析は 容易でないことが予測される。これに対して，我々は，基 礎的な解析の実施に当たり, 応力分布と発熱の要因を取り 除くことが重要と考えた。そこで，均一な一軸性の応力の みをデバイスに印加し，電気特性の変動を計測することと した。また，計測の際のデバイスの発熱は抑制されるよう に考慮した。

応力印加方法については，横型 MOSFET の応力依存性 計測において使用されている4 点曲げ法 ${ }^{(11)}$ をべースに, 縦 型パワーデバイス用に改良した ${ }^{(7)(8)}$ 。Fig. 3(a)に，従来の 4 点曲げ法の模式図を示す。 4 点曲げ法では，内側支点間の シリコン基板の $\mathrm{x}$ 方向の応力は均一であるが，デバイスの $\mathrm{y}$ 方向には応力分布が発生し, 基板の表裏でその值が反転 する。横型 MOSFET の応力依存性の計測であれば，電流 経路が表面 MOS チャネルに限定されるため, y 方向の応 力分布は問題とはならない。一方，縦型デバイスでは，電

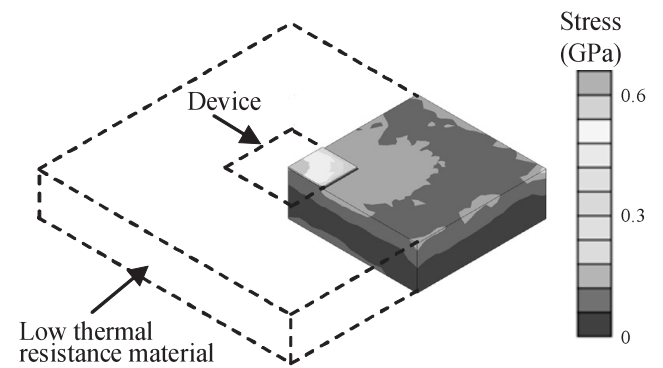

Fig. 2. Thermal stress distribution of high heat dissipation structure 


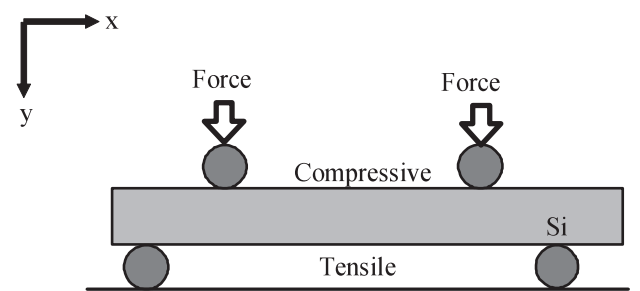

(a) Conventional method

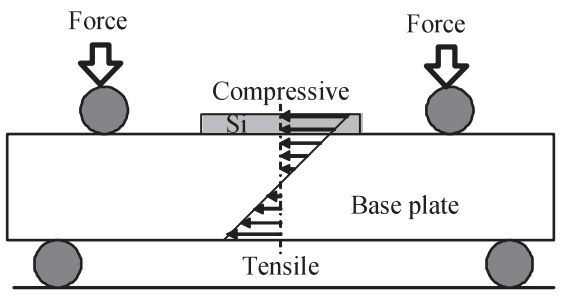

(b) Our method

Fig. 3. Four point bending technique

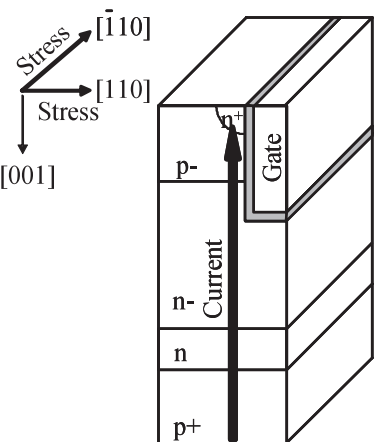

(a) Trench IGBT

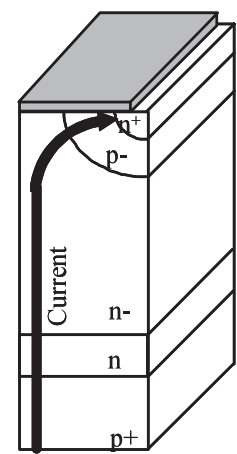

(b) Planar IGBT

Fig. 4. Test device structures

流経路に応力分布が発生することになり，計測結果の解析 は複雑に成らざるを得ない。そこで，デバイス内の y 方向 の応力分布を抑制するために，Fig. 3(b) に示すように，デ バイスをベースプレートに接着した状態で，曲げ応力を印 加することとした。

評価用のデバイスは，Fig. 4 に示すようなプレーナタイ プとトレンチタイプのIGBT を用いた。両者ともシリコン (001) 面上に形成されており, パンチスルー型である。デバ イス表面に平行な [110] 方向と [1110] 方向について一軸性 の機械的応力を印加した状態で, IGBT のオン状態の特性 を室温で計測した。この際, 計測時のデバイスの温度上昇 を抑制するために，カーブトレーサを使用して，短期間パ ルスによる計測を実施した。この際，オン状態のゲート・ エミッタ間電圧は $15 \mathrm{~V}$ で計測した。

なお，本報告では，プラスの符号は引張応力を，マイナ 又符号は圧縮応力を示す。

\section{4. 結果と考察}

Fig. 5 に，トレンチ IGBT の順方向電流電圧特性の応力依 存性を示す。ここでは, 応力として [110] 方向に印加した場 合の計測結果を示している。Fig. 5 より, 電流密度 $10 \mathrm{~A} / \mathrm{cm}^{2}$

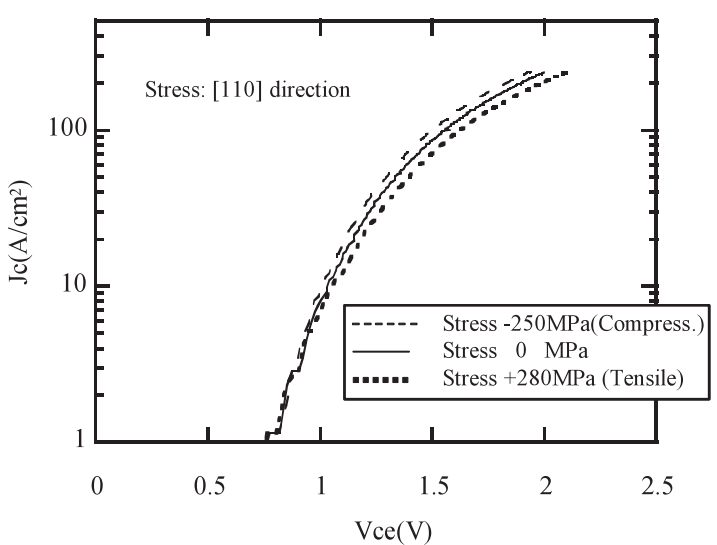

Fig. 5. Stress dependence of on-state characteristics on trench IGBT (Measurement)

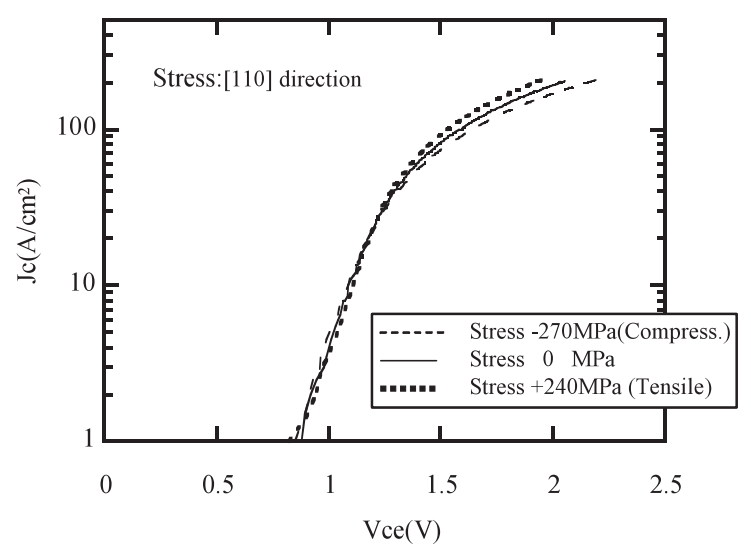

Fig. 6. Stress dependence of on-state characteristics on planer IGBT (Measurement)

以下の低電流域では応力依存性が比較的小さいのに対して, $10 \mathrm{~A} / \mathrm{cm}^{2}$ 以上の比較的高電流域に打いては応力に対する依 存性が観測される。

Fig. 6 に, プレーナ IGBT の順方向電流電圧特性の応力依 存性を示す。ここでも，応力として [110] 方向に印加した場 合の計測結果を示している。Fig. 6 でも, 電流密度 $10 \mathrm{~A} / \mathrm{cm}^{2}$ 以下の低電流域では応力依存性が比較的小さいのに対して, $10 \mathrm{~A} / \mathrm{cm}^{2}$ 以上の比較的高電流域に打いては応力に対する依 存性が観測されている。トレンチIGBT の結果と比較する と，応力による変化の方向性が異なることがわかる。

Fig. 7 に，デバイスシミュレーションによって得られた， トレンチ IGBT のデバイス各部（MOS チャネル，Nドリフ 卜層，拡散電位，P 基板）に抢ける内部ポテンシャルの変 化のシミュレーション結果を示す。なお，本報告のシミュ レーションでは, 前述のポテンシャル変形モデル, 及び, ピ エゾ抵抗効果モデルを使用した。なお，キャリア再結合に 関しては，SRH（Shockley-Read-Hall）モデルを用いてお り, 応力による影響が小さいと考え, その応力依存性は考 慮していない。Fig.7より，MOS チャネルと Nドリフト 層のポテンシャルの応力に対する変化は比較的大きいが, 拡散電位と $\mathrm{P}$ 基板部分の応力に対する変化が小さいことが わかる。拡散電位の応力に対する変動が小さいのは，バン 


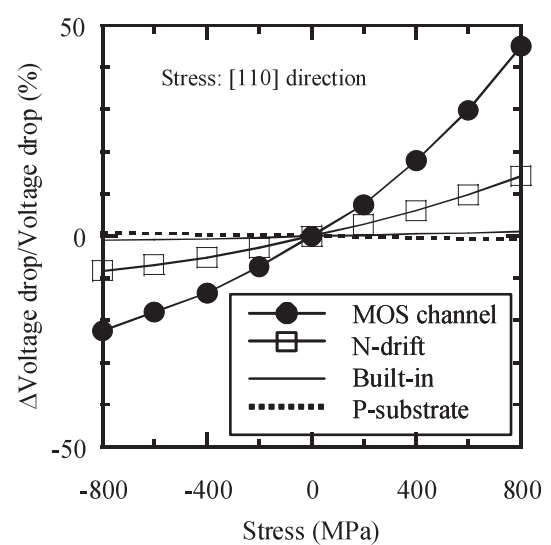

Stress direction

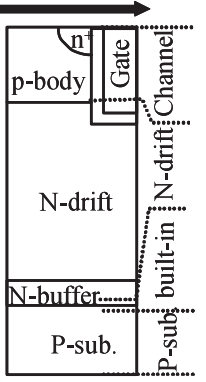

Fig. 7. Voltage drop at $\mathrm{Jc}=230 \mathrm{~A} / \mathrm{cm}^{2}$ of each part on trench IGBT (Simulation)

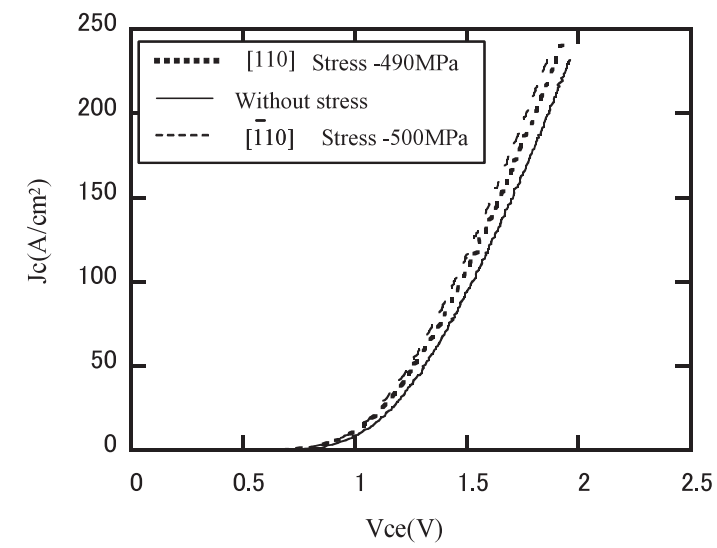

Fig. 8. Stress direction dependence of on-state characteristics on trench IGBT (Measurement)

ドギャップの変動が小さいことに起因していると予測され る（(1)〜(3) 式によれば， $500 \mathrm{MPa}$ の圧縮応力によるバン ドギャップの変化は $30 \mathrm{meV}$ と計算される)。また， $\mathrm{P}$ 基板 の応力に対する変動が小さいのは, Table 1 に示す通り, こ の結晶方位では，正孔のピエゾ抵抗係数が，電子のそれに 比べて，1桁以上小さいことに起因すると考えられる。

Fig. 8 に, トレンチ IGBT の順方向電流電圧特性の応力方 位依存性を示す。ここでは，[110]，[1110]に圧縮応力を印 加した場合の計測結果を示している。Fig. 8より，いずれの 方位に执いても導通損失が低下して抢り，トレンチ IGBT の順方向特性の応力方位依存性は小さいことがわかる。こ れは, MOS チャネルの通電方位 [001] に対して, 応力印加 の方位 [110], [1110]は, 結晶学的に等価であり, キャリア 移動度の応力依存性に差違が発生しなかったためであると 考えられる。

Fig. 9 に, プレーナ IGBT の順方向電流電圧特性の応力 方位依存性を示す。ここでは, [110], [110]に圧縮応力を 印加した場合の計測結果を示している。Fig.9より, プレー ナIGBT の場合，トレンチIGBT とは異なり，印加した応 力の方位により, オン電圧の変化の方向性が異なることが わかる。つまり，[110] 方向の圧縮応力により導通損失が増 加し, [110] 方向の圧縮応力により導通損失が減少すること

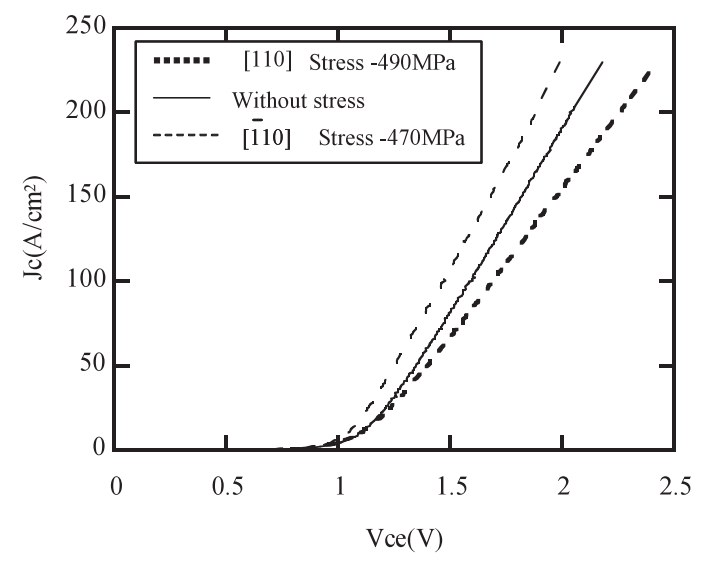

Fig. 9. Stress direction dependence of on-state characteristics on planer IGBT (Measurement)

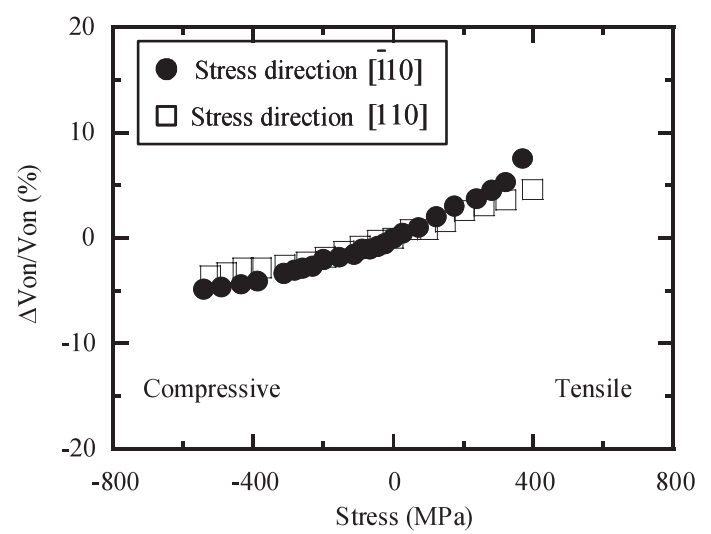

Fig. 10. Stress direction dependence of on-state voltage at $\mathrm{Jc}=230 \mathrm{~A} / \mathrm{cm}^{2}$ on trench IGBT (Measurement)

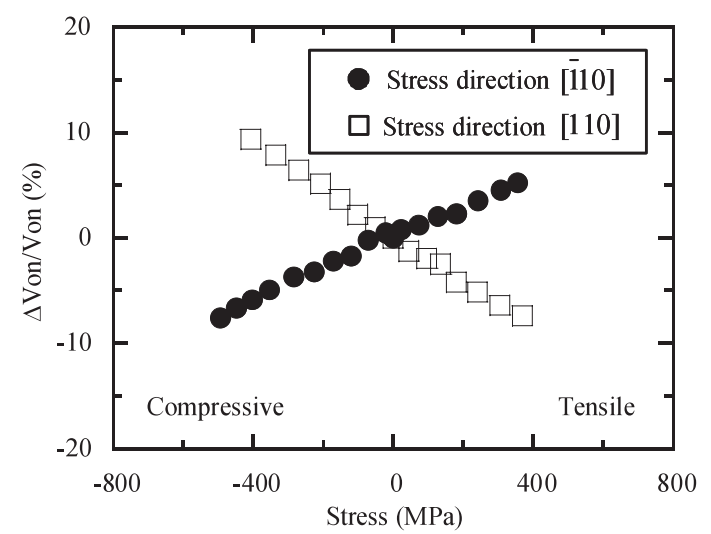

Fig. 11. Stress direction dependence of on-state voltage at $\mathrm{Jc}=230 \mathrm{~A} / \mathrm{cm}^{2}$ on planer IGBT (Measurement)

がわかる。プレーナ IGBT とトレンチ IGBT の構造上の主 要な違いはMOS チャネルの構造にあり, MOS チャネルの 通電方位 [110] に対して, 応力印加の方位 [110], [1110]は, 結晶学的に等価とはいえないため, 変化の方向性に差異が 生じたと考えられる。従って, MOS チャネル部のポテン シャル変化に差異が生じると予測される。さらに, Fig. 10, Fig. 11 に，トレンチ IGBT 及び，プレーナIGBT のオン電 圧の応力依存性の結果を示す。な押, Fig. 10 に扔いて, 応 


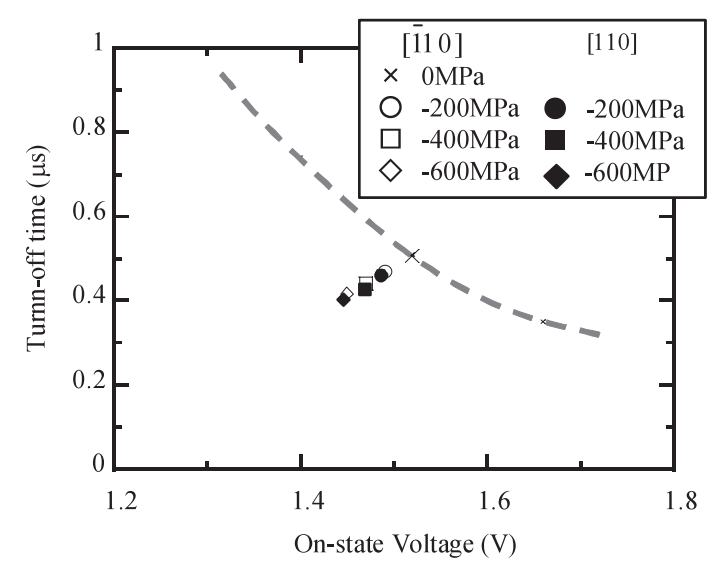

Fig. 12. Relationship in trench IGBT between on-state voltage and turn-off time at $\mathrm{Jc}=230 \mathrm{~A} / \mathrm{cm}^{2}$ (Simulation). Dotted line indicates trade-off relationship between onstate voltage and turn-off time

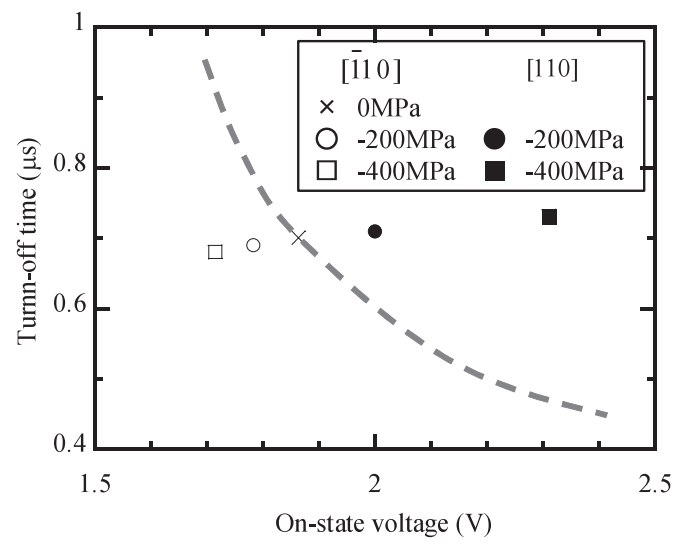

Fig. 13. Relationship in planar IGBT between on-state voltage and turn-off time at $\mathrm{Jc}=230 \mathrm{~A} / \mathrm{cm}^{2}$ (Simulation). Dotted line indicates trade off relationship between onstate voltage and turn-off time

力方位による変動量の差違が小さいながらも見られるが, これは, サンプル間のデバイスの個体差や応力印加の再現 性が誤差要因として含まれているためであると考えられる。

応力印加により, IGBTのキャリア移動度が変化するため, スイッチング特性への影響も予測される。Fig. 12, Fig. 13 に，トレンチ IGBT 及び，プレーナ IGBT の応力によるオ ン電圧とターンオフ時間の変動のシミュレーション結果を 示す。Fig. 12, Fig. 13 には, シリコン結晶のライフタイム を変化させることにより計算したオン電圧，ターンオフ時 間のトレードオフラインも併せてプロット（破線）した。 Fig. 12 より, トレンチ IGBT の場合, [110]，[1110]のいず れの方向であっても，圧縮応力により，デバイス損失が低 下することがシミュレーションにより予測される。これは， 圧縮応力の印加により，電子移動度が増加したためである と考えられる。一方, Fig. 13 より, プレーナIGBT の場合, 応力方位 [110] と [110] では, 損失変化の方向性が異なる ことがシミュレーションにより予測される。つまり，[110] 方向の圧縮応力によりデバイス損失が増加し, [110]方向の

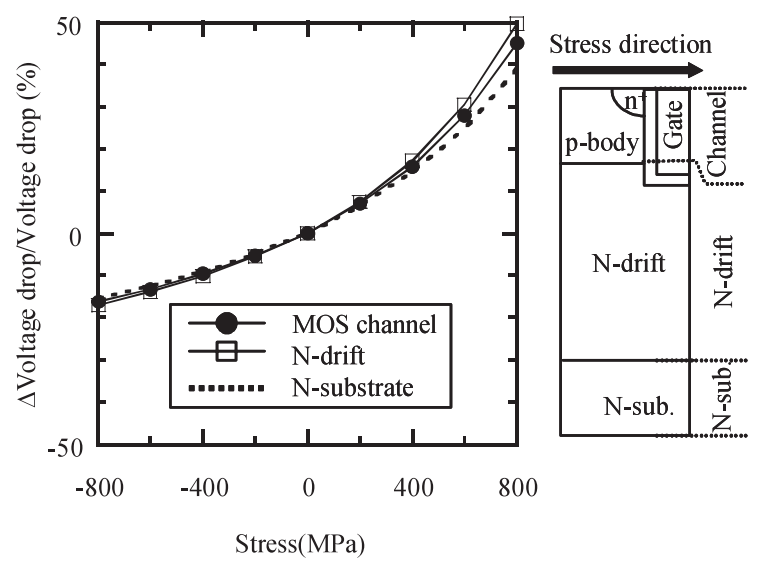

Fig. 14. Voltage drop of each part on trench MOSFET (Simulation)

圧縮応力によりデバイス損失が減少することがわかる。こ れは，応力方位によるMOS チャネル部の電子移動度の影 響が異なることに起因すると考えられる。

これまでは, IGBT の応力依存性について示してきたが, 次に, MOSFET への適用例を示す。Fig. 14 に, デバイス シミュレーションによって得られた，トレンチ型 MOSFET のデバイス各部（MOS チャネル， N ドリフト層， $\mathrm{N}$ 基板） における内部ポテンシャル変化のシミュレーション結果を 示す。Fig. 14 より, MOSFET の場合は, MOS チャネルだ けでなく, N-ドリフト層, $\mathrm{n}$-基板の電圧降下も, 同様に変 化することがシミュレーションにより予測される。これは MOSFET がユニポーラデバイスであるため, 応力による電 子移動度の変化が直接的に影響を与えているためであると 考えられる。

さて，Fig.1(a)，(b)に示すようなモジュール実装工程で は，一般に，加熱接合が想定されるため，工程後のデバイ スには, 主に, デバイス水平面に 2 軸の圧縮応力が残留す る。トレンチタイプの場合, いずれも軸の応力も電子移動 度を増加させるため, ウエ八状態の時に比べて, 実装状態 ではデバイス損失が低下していると考えられる。一方，プ レーナタイプの場合, 応力方位により, 電子移動度の変動 の方向性が異なるため, デバイス損失に対する影響は小さ いと予想される。

また, 以前より, 圧接型のパワーモジュール (12) が提案さ れているが，その実装による影響について，トレンチ IGBT を例に考えてみる。圧接モジュールの場合, トレンチIGBT を実装すると，電流の通電方位である [001] 方向に圧縮応 カが印加されることになる。Table 1 によれば，この場合， 通電方位の電子移動度は低下するため, トレンチ IGBT の オン電圧が増加する方向となることが予測される。

さて, 本報告では, $-500 \sim+500 \mathrm{MPa}$ と比較的広い応力 印加範囲で計測を行った。デバイスに印加される応力は,は んだ材料の物性や基板の熱澎張係数に依存するが, 従来のモ ジュール構造では, デバイスに印加される応力は数 $10 \mathrm{MPa}$ 程度と，それほど大きな值にはならない ${ }^{(13)}$ 。なぜなら，従 
来のはんだ材料の場合は，大きな応力が印加されると塑性 変形するため, その際に応力が緩和されるからである。さ らに，従来のモジュールでは，Fig.1(b) に示すような積層 構造であり，熱膨張係数を段階的に変化させることにより， 熱応力緩和をはかっている。しかし, 最近, パワーモジュー ルの電力密度向上 ${ }^{(1)}$ をらって, 高温動作対応, 及び, 冷却 性能の向上に関する検討が行われている。この高温動作対 応用のはんだ材料 ${ }^{(14)(15)}$ は, 通常のはんだ材料とは異なり, 塑性変形量が小さいため, 応力緩和はそれほど期待できな い。さらに，冷却性向上のために，Fig. 1(a)に示すような デバイスを低熱抵抗材料に実装する構造も提案されている。 こういった低熱抵抗材料の線膨張係数は大きいため，デバ イスに印加される熱応力は大きく成らざるを得ない。した がって，本報告に示した応力がパワーデバイスに与える影 響は，今後の高電力密度モジュールの実現において，設計 上の重要な観点になると考えられる。

\section{5. 結 論}

本報告では，縦型パワーデバイスにおける電気特性の応 力依存性を評価した。デバイスに対する応力の影響を効果 的に抽出するために，均一な一軸性応力を印加した状態で 評価することができる計測方法を開発した。本手法を用い て，トレンチ IGBT のオン状態の電気特性を室温で計測し た。IGBT のオン状態の応力による変動は，主に，電子移 動度の応力依存性に起因しており，MOS チャネル部の影 響が大きいことがわかった。さらに，トレンチ IGBT，プ レーナIGBT を使用したデバイス構造依存性，応力方位依 存性の評価においても，同様の考え方で説明できることを 確認し，スイッチング特性への影響も予測した。さらに， 圧接モジュールのようにデバイス鉛直方向に応力が印加さ れた場合について，デバイス特性に与える影響を予測した。 最後に，パワーモジュールの高温動作化，冷却性能向上と いった今後の技術開発における，本検討内容の必要性を説 明した。

本報告で示したパワーデバイスの応力依存性の知見は, 高電力密度化されたパワーモジュールの信頼性向上に対し て重要な役割を果たすものと考えられる。

(平成 19 年 3 月 23 日受付，平成 20 年 1 月 7 日再受付)

\section{文献}

(1) A. Kawahashi: "A New-Generation hybrid electric vehicle and its supporting power semiconductor devices", Proc. of Int. Symp. on Power Semiconductor Devices and ICs, pp.23-29 (2004)

(2) M. Ishiko: "Recent R\&D activities of power devices for hybrid electric vehicles", REDD Review of Toyota CRDL, 39-4, pp.1-6 (2004) (in Japanese) 石子雅康：「ハイブリッド自動車用パワーデバイスの研究開発」, 豊 田中央研究所 R\&D レビュー, 39-4,pp.1-6 (2004)

(3) T. Sasaki, H. Takao, T. Shikano, S. Fujita, D. Nakajima, and T. Shinohara: "Development of High Current Transfer-mold type Power Module with High Heat-cycle Durability", Proc. of Int. Symp. on Power Semiconductor Devices and ICs, pp.293-296 (2004)

(4) M. Otsuki, H. Kanemaru, Y. Ikeda, K. Ueno, M. Kirisawa, Y. Onozawa, and Y. Seki: "Advanced thin wafer IGBTs with new thermal management solution", Proc. of Int. Symp. on Power Semiconductor Devices and ICs, pp.144-147 (2003)

(5) M. Ciappa: "Selected failure mechanism of modern power modules", $M i-$ croelectronics and Reliability, 42, pp.653-667 (2002)

(6) G. Lefranc, T. Licht, and G. Mitic: "Properties of solders and their fatigue in power modules", Microelectronics and Reliability, 42, pp.16411646 (2002)

7 M. Usui, M. Ishiko, K. Hotta, S. Kuwano, and M. Hashimoto: "Effects of uni-axial mechanical stress on IGBT characteristics", Microelectronics and Reliability, 45, pp.1682-1687 (2005)

（8）桑野 聡・堀田幸司・橋本雅人·白井正則・石子雅康：「IGBT の一軸性 機械的応力依存性」, 電子デバイス/半導体変換装置合同研資, pp.65-69 (2005)

(9) J.J. Wortman, J.R. Hauser, and R.M. Burger: "Effects of stress on p-n junction device characteristics", J. of Applied Physics, 35, pp.2122-2131 (1964)

10) C.S. Smith: "Piezoresistance effect on germanium and silicon", Physical Review, 94, pp.42-49 (1954)

11) C. Gallon, G. Reimbold, G. Ghibaudo, R.A. Bianchi, and R. Gwoziecki: "Electrical analysis of external mechanical stress effects in short channel MOSFETs on (001) silicon", Solid-State Electronics, 48, pp.561-566 (2004)

12) S. Kaufmann, T. Lang, and R. Chokhawala: "Innovative Press Pack Modules for High Power IGBT's", Proc. of Int. Symp. on Power Semiconductor Devices and ICs, pp.59-62 (2001)

（13） 三浦英生・西村朝夫 ·河合末男 - 西 邦彦：「IC プラスチックパッ ケージ内シリコンチップの残留応力の検討」, 日本機械学会論文誌 (A 編), 55, pp.1763-1770 (1989)

(14) F.P. McCluskey, M. Dash, Z. Wang, and D. Huff: "Reliability of high temperature solder alternatives", Microelectronics and Reliability, 46, pp.19101914 (2006)

(15) Y. Yamada, Y. Takaku, Y. Yagi, Y. Nishibe, I. Ohnuma, Y. Sutou, R. Kainuma, and $\mathrm{K}$. Ishida: "Pb-free high temperature solders for power device packaging", Microelectronics and Reliability, 46, pp.1932-1937 (2005)

臼 井 正 則 (非会員) 1990 年 3 月名古屋工業大学大学院工

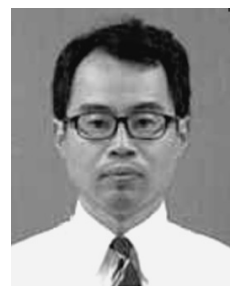
学研究科電気情報工学専攻博士前期課程修了。同 年，(株）豊田中央研究所入社。現在，自動車用 パワーデバイス，モジュールの信頼性評価技術の 研究開発に従事。

田 中 宏 明 (非会員) 2001 年 3 月名古屋工業大学大学院工

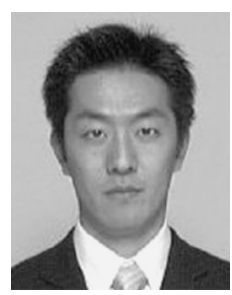
学研究科都市循環システム工学専攻修士課程修了。 同年，トヨ夕自動車（株）入社。現在, 自動車用 パワーデバイスの技術開発に従事。

堀 田 幸 司 (非会員) 1995 年 3 月名古屋大学大学院工学研

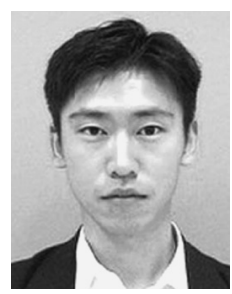
究科結晶材料工学専攻博士前期浬程修了。同年, トヨタ自動車 (株) 入社。以来, 自動車用パワーデ バイスの技術開発に従事。現在，パワーモジュー ルの技術開発に従事。 
桑 野 聡 (正員) 1996 年 3 月九州大学工学部電気工学科卒

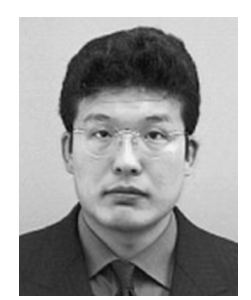

石 子 雅 康 (正員) 1983 年 3 月名古屋大学工学研究科電気 業。2001 年トヨタ自動車 (株) 入社。現在, 自動 車用パワーデバイスのプロセス技術開発に従事。 工学専攻博士前期課程修了。1990 年, (株) 豊田 中央研究所入社。主に SI デバイス, IGBT および

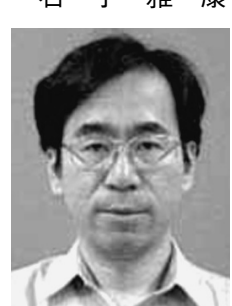
FWD など $\mathrm{Si}$ パワーデバイスと自動車へのデバイ 又応用技術に関する研究開発に従事。現在, 同パ ワーデバイス研究室長。 